\title{
INVESTIGATING LEARNERS' OBSTACLES IN SECOND LANGUAGE READING COMPREHENSION
}

\author{
${ }^{1}$ Safrudin Sahmadan, Ali Ajam ${ }^{2}$ \\ ssahmadan91@gmail.com; aliajam@gmail.com \\ ${ }^{1}$ Program studi pendidikan bahasa Inggris, Universitas Bumi Hijrah, Maluku Utara \\ ${ }^{2}$ Program studi pendidikan bahasa Inggris, Universitas Khairun, Maluku Utara
}

\begin{abstract}
Skill in reading texts written in English as a foreign language constitutes a fundamental element of the establishment of English curriculum in Indonesia. The aim of this article is to investigate and explore the obstacles and difficulties faced by Indonesians in their learning activities which hampering the learners in gaining comprehension, and to view the pedagogy from the broader perspective on the theories of reading process. As the writer found, the learners are lack of language system understanding, lack of reading strategies, poor in recognizing the types of reading comprehension. Therefor, through literary study as the research method, the result appeared that the obstacles and problems faced by the Indonesian affected by cultural background, English teaching and learning process, and approaches in teaching and learning.
\end{abstract}

Key words: Reading comprehension, Reading obstacles, Reading Comprehension problem

\section{INTRODUCTION}

Reading in English has become a fundamental skill in term of academic learning and career (Anderson \& Cheng, 2004; Grabe \& Stoller, 2019). Further, the ability of L2 reading has become a basic demand as English such as an international language, as the language of science, technology and advanced research in accordance with fast technological development and a wide amount of information available in English (Grabe \& Stoller, 2019). In short, the importance of reading in English as L2 involves its role in developing L2 academic competencies, interpersonal communication, exposure to L2 culture, learning about technological developments and scientific discoveries, providing input in the form of printed books and journals, computers and the internet.

Developing strong reading skills in students is one of the key goals of every early education program. It is through reading that students expand their vocabulary and learn about the world. Reading is also the key to success in spelling and writing. The reading skill are closely associated with the people's prosperities (Kumar et al., 2016). The better reading abilities also enable people becoming successful in their academic pursuit (Iftanti, 2015). The people with better reading comprehension skills also obtain greater opportunities to brighter career promotion (Wei et al., 2016). Despite of these important roles of the reading skills, the literacy level of Indonesian people unfortunately is listed among the worst in the world in the level of 60 of 61 countries (Gunawan, 2016).

A significant role of L2 development is strenghthening L1 literacy skills, both reading and writing, as "it has been shown that a learner's understanding of his native language is enhanced by learning a foreign one (as he or she) becomes more conscious and deliberate in using words as tools of his thought and expressive means for his ideas". On the other hand, despite most learners acquire literacy skills relatively easily, difficulties appear both in L1 and L2 reading. Hannell, (2008) argues that 15 per cent of learner's experience some form of reading difficulties, from mild to severe, resulting in motivational and emotional challenges, like embarrassment, frustration, and angriness.

In line with this, it is important to determine a learner's reading difficulties, as well as the factors behind her or his slow and/or inaccurate reading or problems with reading comprehension in both $\mathrm{L} 1 / \mathrm{L} 2$, and to give her or him timely help, so that she or he can achieve full potential in linguistic and academic development. As Geva, (2006) stresses that the same processing factors 
determine literacy development both in L1 and L2, so that if they facilitate L1 literacy acquisition, they can facilitate L2 reading development in the same way. She added also that positive transfer of reading skills can be expected from L1 to L2, and from L2 to L1, but so can negative transfer as well, having "important implications for assessment of minority or bilingual children who are atrisk for having a reading disability".

\section{The students' failure in second language reading}

Up to now, most students or learners still faced difficulties to comprehend a text. They are still lack of comprehension in second language reading. Natsir \& Anisati (2016) remark that there are still many students who have less comprehension on English reading texts. Further, refers to the children's reading difficulties, there are a number of findings revealed that second language learner have similar trouble in decoding and spelling of L1 and L2, and the differences of individual learner such irrespective of the differences of the orthographies; phonological knowledge, rapid naming and verbal working memory are can predict reading difficulties in L1 (Geva, 2006).

\section{The reason for students' failure in second language reading}

Concerning to the students' difficulties and the reason, Geva (2006) states that the obstacle of L2 learners' reading comprehension is affected by less of word-based reading skills included word recognition, pseudo word decoding, and phonological knowledge. In addition, unfamiliar with particular language structure and features of the text of readers offend them in gaining comprehension and their language-processing ability break down. Further, students who are less interested in reading, with low motivation use few metacognitive strategies to monitor their learning from the text, and have inadequate vocabulary and background knowledge with which to connect and link new ideas to previous learning are often failed in reading comprehension.

Additionally, based on the interviews with both the English teacher appeared that the students faced difficulties in English because they have inadequate vocabulary, lack of grammatical complexity, and also they have no prior knowledge about the different types of reading. Further, another issue in second language reading is that the less of reading practice affect students to achieve their reading comprehension skill (Rochman, 2017).

\section{The construction of $\mathrm{L} 2$ reading comprehension}

To increase learner's knowldge and comprehension in second language reading, there are several strategies that can be applied in teaching and learning reading process, such as activate ideas or build learner's schemata, build vocabulary and grammar, etc. that include semantic mapping and experience text relationship method (Fahmi, 2003). In addition, incorporating the reading strategies in teaching reading should be carried to assist students to be successful readers (Fitrisia et al., 2015).

Additionally, to activate the learner's schemata or prior knowledge of a topic and take guesses about what they are read about by analyzing pictures and titles or skimming a text to assess the main idea. Further, it can be also conducted by create mind-maps as a pre-reading activity or put a few questions on the board and have the students start by discussing them in order to prepare for the reading. In addition, the more words a student or learner knows, the easier it will be to recognize them in reading. Teaching vocabulary is also helpful for spelling skills. Teachers can provide a glossary alongside a text or pre-teach key terms before the reading begins. As learning words in context provides additional depth in meaning, teachers might also consider providing instruction on contextual guessing.

Additionally, refers to the issue about practices that can help students in obtaine or develope their comprehension in reading, Rustipa, (2014) acknowledges that by practices learners or students have opportunities to gain their reading proficiency. Further, She added that adding time 
allotment for English learning may become a solution to this issue (Ruspita, 2014). In line with this, a reading practice be able to promote learners language development (Harmer, 2002).

\section{METHOD}

The method used in this study is literary studies. The researcher searched Indonesian students' reading comprehension obstacles though English journal articles. In gathering journal articles, the researcher employed a search engine: google scholar. The articles searched by the researcher were explicitly containing the researches who have conducted in Indonesia and deals with English reading comprehension problems.

The researcher used keywords of "learners' obstacles in L2 reading comprehension in Indonesia" in the search engines. The articles are then analyzed using thematic analyses to explore the existing problems in English reading comprehension problems in Indonesia.

\section{DISCUSION}

The data analysis for the research articles appeared that English reading obstacles that exist in Indonesia comprise of cultural-based issues, English teaching and learning problem and teachers' exemplary and ways of teaching. In line with this, there are some issues in second language reading that hamper the learner's comprehension in reading as described bellow.

\section{Cultural issues in reading comprehension.}

Based on the finding reveal that Indonesian learners problems in second language reading comprehension affected by several issues include cultural-based issues (Suryanto, 2014). As Masduqi, (2014) formulates that culture as the one obstacle that hamper the students' reading comprehension. In addition, refers to the cultural problem, he suggest that English teachers in Indonesia should be aware of these cultural problems and be encouraged to create supporting conditions for effective, learner-centred teaching in their reading classes (Masduqi 2014).

Indonesian dominant cultures amongst spoken and written are different wherein the spoken cultures the speakers to comprehend the oral communication they do not need to decode the meaning through written symbols (Cornoldi \& Oakhill, 1996). Culture as one of the barriers that offend students' comprehension. Students inability to obtain comprehension because they are lack of language system understanding and it caused Indonesian and English owns different phonetic classification and symbols (Weda \& Sakti, 2018).

In addition, refers to the factors which influence EFL reading skills, Imran, (2006) reveales that cultural background affected individual differences in reading behavior and these individual differences, in turn affected students EFL reading performance. Moreover, he notes that reading performance could be improved by providing sufficient opportunities to increase students' motivation and confidence as well as knowledge of subject areas and language in learning. Thus, in order to be more confident and autonomous readers, according to Imran (2005: 22), EFL learners should be helped to enhance their ability and willingness to learn.

Additionally, the one of cultures is students have impolite behavior to the teacher such differ from the teachers as the students' knowledge is not comparable yet to their teacher (Masduqi, 2014). This culture as one of obstacle which obstruct or impede the students' development in learning processes as they should follow whatever teachers teach. Otherwise, students are seem have disrespect of relationship with their teachers (Suryanto, 2014). 


\section{Teaching and learning issues}

The one barrier in achiving comprehension is dealing with attitude in teaching and learning processes. The attitude is refers to the students' inaction in learning and teaching activities process (Natsir \& Anisati, 2016; Suryanto, 2014). The students' learning and classroom activities achieved depend on a serious attitude (Pamuji, 2015). Further, to make students' learning is being active, motivating them, and ensuring their comprehension toward the lesson; teachers have to struggle and extra work (Damayanti, 2017).

In line with activates and motivates students' learning to gaine reading comprehension, teacher should provides or apply appropriate strategies in teaching and learning activity. However, students are still lack of reading strategies. Refers to the strategies, According to Mistar et al., (2016) that predicitng, text mapping, and summarizing are the strategies to be effective readers. Similarly, Fitrisia, Tan, and Yusuf (2015) revealed that slowing down the reading to better understand the text, focusing on certain text, adjusting the reading speed, pausing and thinking about the text, visualizing the information read, repeat the reading processes, and guessing meaning of unfamiliar words are the applicable reading strategies in order to be effective readers. On the other hand, students comprehension can be developed by build students' schemata which is including semantic mapping and experience text relationship method. Further, they added also that incorporating the reading strategies in teaching reading should be carried to assist students to be successful readers (Fitrisia et al., 2015; Latif, 2016).

In the other side, students also have low knowledge of the text genre which are the different text genres indicate different types of texts. Inability to recognize kinds of genres is make students lack of reading comprehension skills. The higher the students' awareness on the reading texts, the higher the students' reading comprehension skills are. In line with this, Rukmini, (2004) hypothesized that the reasons behind students lack of interest in reading was students unfamiliarity with various genres employed in reading texts. In her report of genre analysis, she found that most reading texts used were anecdote and descriptive texts.

Additionally, Hamra \& Syatriana, (2015); Lie, (2007) pointed out that mostly learners have weakness in comprehending information from reading texts. Further, the learners were also inability to obtain meaning using contextual clues (Fitrisia, Tan, \& Yusuf, 2015). In addition, another fact the students' English reading fluencies are low is that they have less knowledge and ability to comprehend analytical exposition (Komariah et al., 2015).

In line with this, there is a follow up study Fahmi (2003) states that the students also faced difficulties when the texts used were long and/or the sentences in the texts were long and complicated with various different modifying phrases. The students faced these difficulties because the texts or sentences used were long, unfamiliar vocabulary, lack of pre-reading activity that activates prior knowledge, and repetitive teaching. It is believed that if the students have adequate vocabulary and good grammar comprehension, the length of the text used in the test will not be a problem and they will be able to comprehend the text easily. He further added that another reason why the students faced difficulties was the students did not have sufficient background knowledge to understand the texts, the lessons had not been learnt properly and/or they had never read a similar text before (Fahmi, 2003). In line with this, the students faced difficulties in reading because they had not mastered a wide range of vocabulary and grammar and did not have good understanding about the different types of reading comprehension questions (Cahyono \& Widiati, 2006). On the other hand, Accordding to Lie (2007), the other one of the issues that potentially appears English reading comprehension problem in learning process is the number of students which is reduces the chances for students to gained facilitation for their teachers. 


\section{Teachers' examplary}

The availability of a good examples by teacher in the process of teaching and learninng as a prominent supporting students' comprehension, however mostly English teachers do not applied that. This is obvious as they are not active English user in their communities (Lie, 2007). Indonesian people traditionally places teachers as knowledgeable people that they refer to. When the people they refer to do not use English, they tend to follow their steps. This learning condition may also become a problem that influences students in learning English reading comprehension skills. In addition, Cahyono \& Widiati (2006) appear that the students are poor in recognizing the types of reading comprehension question because the teacher did not teach them about the different types of reading comprehension questions. Because of these problems, the students failed the reading comprehension test.

\section{Teachers ways of teaching}

The ways of teaching needs to be more interesting. Teachers still need a reform on their teaching method in order to design more interesting materials. In addition, Astika, (2015) appears that the interesting authentic materials which are developed wealthy rich contextual cues to understand the content facilitate students to have better learning outcome. Additionally, According to Tupan (2004) one way to improve reading skills is to provide students with authentic materials, especially advertisements. In her views, written advertisements could be good reading materials to train learners to think critically to reveal the hidden message. She also recommended teachers use advertisements in the reading classroom through some stages, among others, discussing the claims or language styles and encouraging the learners to get the intended meaning of the advertisements (Tupan, 2004).

On the other hand, Natsir \& Anisati, (2016) remark that there are still many students who have less comprehension on English reading texts, then teachers are demanded to set and apply the appropriate teaching strategies to enhance the students' reading skills (Fitrisia, Tan, \& Yusuf, 2015; Mistar, Zuhairi, \& Yanti, 2016). As many teachers who still have deficiency of theoretical foundations to apply in their classroom practices (Cahyono \& Widiati, 2006; Lie, 2007). Another issue in teaching reading is that the less of reading practice which is can help students to achieve their reading comprehension skill (Rochman, 2017).

\section{The Implication}

In line with the obstacles that hampering the learners in obtaine reading comprehnsion and the solutions as discussed in the prevous section, the implications for the classroom are that constant guidance and support over time are essential in order to help teachers use those approaches or ways in the process of learning. In addition, expected that it gives an understanding to neither teachers nor students about reading problems faced by the learners and how to resolves it. In addition, teachers are expected and demanded to use or apply those strategies in teaching and learning practices in order to help learners to enhance their understanding and comprehension in reading.

\section{CONCLUSSION}

This article has reviewed several finding about the issues of second language reading difficulties and the obstacles which is hampering the students' reading comprehension in Indonesia. As what have discussed in the previous phase, students or learners in Indonesia still face many barriers culturally in order to gain good reading comprehension skills. Students difficult to 
obtaine comprehension in reading caused by weakness of word-based reading skills, included word recognition, pseudo word decoding, and phonological knowledge.

Additionaly, students also relative inactive that affect their learning process to achieve their comprehension in reading. Further, students' inaction in learning activity caused by they do not understand the subject provided and they unfamiliar with the vocabulary. In addition, students are lack of reading comprehension also effected by having low of knowledge about the second language system. Similarly, it happened also influenced by the insufficient time provided to practices and inadequate reading strategies. In short, reading comprehension is complicated to obtained by the students or learners caused they have weaknes of vocabulary and grammar, less of bakcground knowledge, lack of strategies and in practicing, and the limited time for learning and practice that can affect to the students' mastery in reading ability.

On the other hand, refers to the achievement of reading comprehension, the are some theories which are suggesting the solutions or approaches that can help learners in achiving reading comprehension. Those ways or approaches comprise of such as activate build learner's schemata, vocabulary, etc. that include semantic mapping and experience text relationship method where vocabulary and schemata can be created through dictionary and marginal glosses (Fahmi 2003). Additionally, comprehension in reading can be gained also by applying precise strategies and also practices in teaching and learning process (Fitrisia, Tan, \& Yusuf, 2015; Mistar, Zuhairi, \& Yanti, 2016; Ruspita 2014).

\section{REFERENCES}

Anderson, N. J., \& Cheng, X. (2004). Exploring second language reading: Issues and strategies. Foreign Language Teaching and Research Press.

Astika, G. (2015). Profiling the vocabulary of news texts as capacity building for language teachers. Indonesian Journal of Applied Linguistics, 4(2), 123-134.

Cahyono, B. Y., \& Widiati, U. (2006). The teaching of EFL reading in the Indonesian context: The state of the art. Teflin Journal, 17(1), 36-58.

Cornoldi, C., \& Oakhill, J. (1996). Introduction: Reading comprehension difficulties. Reading Comprehension Difficulties Processes and Intervention.

Damayanti, I. L. (2017). From storytelling to story writing: The implementation of reading to learn (R2L) pedagogy to teach English as a foreign language in Indonesia. Indonesian Journal of Applied Linguistics, 6(2), 232-245.

Fahmi, A. (2003). Activating learner long-term memory in teaching EFL reading. NUESP [Network of University ELT Service Providers] National Conference, Jember, Indonesia.

Fitrisia, D., Tan, K.-E., \& Yusuf, Y. Q. (2015). Investigating metacognitive awareness of reading strategies to strengthen students' performance in reading comprehension. Asia Pacific Journal of Educators and Education, 30(1), 15-30.

Geva, E. (2006). Learning to read in a second language: Research, implications, and recommendations for services. Encyclopedia on Early Childhood Development, 1-12.

Grabe, W., \& Stoller, F. L. (2019). Teaching and researching reading. Routledge.

Gunawan, A. S. (2016). Indonesia second least literate of 61 nations. In The Jakarta Post, on March (Vol. 12). 
Hamra, A., \& Syatriana, E. (2015). Developing a model of teaching reading comprehension for EFL students. TEFLIN Journal, 21(1), 27-40.

Hannell, G. (2008). Success with inclusion: 1001 teaching strategies and activities that really work. Psychology Press.

Harmer, J. (2002). The Practice of English Language Teaching 3 rd Edition Completely Revised and Up Date. In Halow Pearson Education Limited.

Iftanti, E. (2015). What makes EFL students establish good reading habits in English. International Journal of Education and Research, 3(5), 365-374.

Imran, N. (2006). The interplay of culture, individual differences and adult EFL reading performance: From teacher-dependence to the development of autonomous readers. 54th TEFLIN International Conference Held in Salatiga, Indonesia.

Komariah, E., Ramadhona, P. A. R., \& Silviyanti, T. M. (2015). Improving reading comprehension through reciprocal teaching method. Studies in English Language and Education, 2(2), 87102.

Kumar, N., Kumar, N., \& Rani, R. (2016). Gender disparity in literacy: Districts level evidence from selected states of India. Educational Quest-An International Journal of Education and Applied Social Sciences, 7(3), 243-254.

Latif, S. (2016). Analisis Kesalahan Mahasiswa Semester II Program Studi Pendidikan Bahasa Inggris dalam Menggunakan Kata Kerja Bantu dalam Menulis di Universitas Khairun. EDUKASI, 13(1).

Lie, A. (2007). Education policy and EFL curriculum in Indonesia: Between the commitment to competence and the quest for higher test scores. TEFLIN Journal, 18(1), 1-15.

Masduqi, H. (2014). EFL reading in Indonesian universities: Perspectives and challenges in cultural contexts. Journal of Teaching and Education, 3(03), 385-397.

Mistar, J., Zuhairi, A., \& Yanti, N. (2016). Strategies Training in the Teaching of Reading Comprehension for EFL Learners in Indonesia. English Language Teaching, 9(2), 49-56.

Natsir, Y., \& Anisati, A. (2016). The Matters in Teaching Reading Comprehension to EFL Students. Studies in English Language and Education, 3(1), 65-78.

Pamuji, A. (2015). The correlation among attitude, reading comprehension, and writing achievement of English education study program students of Sriwijaya University. Jurnal Adminika, 1(1).

Rochman, M. (2017). The importance of teaching reading: Emphasize for reading fluency or accuracy in improving students' reading comprehension in EFL context. Ethical Lingua: Journal of Language Teaching and Literature, 4(1), 11-29.

Rukmini, D. (2004). Genre analysis of the reading texts in the English text book for for high school students published by Balai Pustaka. The 52nd TEFLIN International Conference, Palembang.

Rustipa, K. (2014). Metadiscourse in Indonesian EFL learners' persuasive texts: A case study at English Department, UNISBANK. International Journal of English Linguistics, 4(1), 44. 
Suryanto, S. (2014). Issues in teaching English in a cultural context: A case of Indonesia. The Journal of English Literacy Education: The Teaching and Learning of English as a Foreign Language, 1(2), 75-82.

Tupan, A. (2004). Improving Learner's Reading Skill Through Advertisements. TEFLIN Conference.

Weda, S., \& Sakti, A. E. F. (2018). Formal Instruction and Its Effects on the Acquisition of English Affricate Consonants. International Journal of Academic Research in Progressive Education and Development, 7(3), 1-13.

Wei, H., Cromwell, A. M., \& McClarty, K. L. (2016). Career readiness: An analysis of text complexity for occupational reading materials. The Journal of Educational Research, 109(3), 266-274. 